Abstracta Iranica Iranica

Revue bibliographique pour le domaine irano-aryen

Volume 37-38-39 | 2018

Comptes rendus des publications de 2014-2016

\title{
Louise W. Mackie. Symbols of Power: Luxury Textiles from Islamic Lands, 7th-21st Century
}

\section{Yuka Kadoi}

\section{Q OpenEdition \\ 1 Journals}

\section{Electronic version}

URL: http://journals.openedition.org/abstractairanica/43195

DOI: 10.4000/abstractairanica.43195

ISBN: 1961-960X

ISSN: 1961-960X

Publisher:

CNRS (UMR 7528 Mondes iraniens et indiens), Éditions de l'IFRI

Electronic reference

Yuka Kadoi, « Louise W. Mackie. Symbols of Power: Luxury Textiles from Islamic Lands, 7th-21st Century ", Abstracta Iranica [Online], Volume 37-38-39 | 2018, document 10, Online since 30 December 2018, connection on 02 October 2020. URL : http://journals.openedition.org/abstractairanica/43195; DOI : https://doi.org/10.4000/abstractairanica.43195

This text was automatically generated on 2 October 2020 .

Tous droits réservés 


\title{
Louise W. Mackie. Symbols of Power: Luxury Textiles from Islamic Lands, 7th-21st Century
}

\author{
Yuka Kadoi
}

\section{REFERENCES}

Louise W. Mackie. Symbols of Power: Luxury Textiles from Islamic Lands, 7th-21st Century. New Haven/London: Yale University Press/Cleveland Museum of Art, 2015, 520 p., 493 color + 20 b/w ill.; ISBN: 978-0300206098

1 This lavishly illustrated and physically imposing volume - a winner of the 24th I.R. Iran World Award for Book of the Year (2017) - has been published as the result of a longterm research endeavour by Louise W. Mackie, an internationally renowned expert of Islamic textiles and a former curator of textiles and Islamic art at the cleveland Museum of Art. With more than 500 illustrations, mostly in color, Symbols of Power offers an unparallel amount of information on the historical and cultural significance of Islamic textiles. Drawn from not only the Cleveland's collection but also a wide selection of textile collections worldwide, it provides a comprehensive picture of the development of textile industries across the Islamic world.

2 This study is chronologically divided into eleven chapters. Each chapter reviews familiar stories and incorporates new thoughts. Many of the well-studied Persian examples, as well as unpublished examples from modern-day Iran, India and Central Asia, are featured in this book. Of particular interest for Persian art historians is the overview of the so-called "Buyid textile", a group of medieval textile fragments from the excavation of the Bibi Shahrbanu site (1924-5) which became a subject of heated debate in terms of their authenticity (summarised in pages 154-5). The chapter of the modern era $1840-2010$ is a much-needed contribution to the scholarship of Islamic textiles (pages 445-65), supplemented by the reading of inscriptions on select pieces 
and the glossary of technical terms. The content of endnotes is overwhelmingly rich in information, followed by a relatively short yet concise list of references.

3 Symbols of Power remains as an authoritative, must-read source for any future study of Islamic textiles. Moreover, the book itself serves as a luxurious visual tool for searching weaving technologies and textile designs, interwoven with their political and economic background.

\section{AUTHORS}

\section{YUKA KADOI}

University of Edinburgh 